\title{
Household Livelihood Strategy Based on Capital Assets in Fire-Prone Areas, Ogan Komering Ilir Regency, South Sumatra
}

\author{
Ari Nurlia ${ }^{1,2^{*}}$, Dadang Hikmah Purnama ${ }^{3}$, Sabaruddin Kadir ${ }^{4}$ \\ ${ }^{1}$ Master Programme on Environmental Management, Universitas Sriwijaya. Jl. Padang Selasa No. 524, Bukit Besar, Palembang, \\ 30139, Sumatera Selatan, Indonesia \\ ${ }^{2}$ Environmental and Forestry Research and Development Institute of Palembang. Jl. Kol. H. Burlian Km. 6, Alang-Alang Lebar, \\ Palembang, 30961, Sumatera Selatan, Indonesia \\ ${ }^{3}$ Department of Sociology, Faculty of Social and Political Sciences, Universitas Sriwijaya. J1. Raya Palembang - Prabumulih KM \\ 32, Indralaya, Ogan Ilir, 30662, Sumatera Selatan, Indonesia \\ ${ }^{4}$ Departement of Soil Science, Faculty of Agriculture, Universitas Sriwijaya. J1. Raya Palembang - Prabumulih Km. 32, Indralaya, \\ Ogan Ilir, 30662, Sumatera Selatan, Indonesia \\ *Corresponding author. E-mail address: ari_nurlia@yahoo.com
}

ARTICLE HISTORY:

Received: 30 August 2020

Peer review completed: 24 September 2020 Received in revised form: 21 October 2020 Accepted: 27 January 2021

\section{KEYWORDS:}

Forest and land fires

Livelihood asset

Livelihood strategies

(C) 2021 The Author(s). Published by Department of Forestry, Faculty of Agriculture, University of Lampung in collaboration with Indonesia Network for Agroforestry Education (INAFE) This is an open access article under the CC BY-NC license:

https://creativecommons.org/licenses/by$\mathrm{nc} / 4.0 \%$

\begin{abstract}
Forest and land fires are problems that have not been resolved and occur almost every year. Various policies related to forest and land fires began to be promoted nationally and have restricted communities in managing their land. This causes a vulnerability in society. Farmers are required to carry out various methods and strategies to overcome economic problems. This research aims to analyze the livelihood assets and livelihood strategies of farmer households. The study was conducted from February to June 2020 in Pulu Beruang Village, Tulung Selapan Sub-District, and Kayu Labu Village, Pedamaran Timur Sub-District, Ogan Komering Ilir Regency. This research is a survey research using a mixed sequential explanatory approach by using the triangulation principle. The quantitative data collection is done through a household survey using a questionnaire to 75 respondents in Pulu Beruang Village and 70 respondents in Kayu Labu Village. Qualitative data collection was carried out through in-depth interviews, Focus Group Discussions (FGD), and field observation. The results showed that Pulu Beruang Village had a greater asset score in human capital and financial capital. In comparison, Kayu Labu Village had a greater score in natural capital. Physical capital and social capital in both villages had scores that were not distinctly different. Hence, they did not have a different effect on community resilience. Livelihood assets owned by the community influence their household livelihood strategies. The household livelihood strategy in Pulu Beruang Village uses human capital and financial capital, agricultural sector and non-agriculture, especially trading, and swallow's nest business. Meanwhile, the livelihood strategies of farmers' households in Kayu Labu Village rely on their natural capital and agricultural sectors, such as fisheries and purun crafts.
\end{abstract}

\section{Introduction}

Forest and land fires are serious problems that have yet to be adequately handled (Syaufina and Hafni 2018). Longstanding efforts have been conducted to overcome this problem, but the success was relatively low (Cahyono et al. 2015). Forest and land fires are caused by complex 
multi-factors, including physical aspects (fuel and climate), ecology, socio-economic and anthropological culture of society, technology and institutional systems, forest and land management intensity, and silvicultural aspects (Akbar 2016). Forest fires are not natural disasters because most of the incidence of forest and land fires in Indonesia are caused by human factors (anthropogenic), especially those related to efforts to fulfill daily needs, plantation activities, and land conflicts (BNPB 2014; Budiningsih 2017; Sukarman 2017).

South Sumatra is one of the provinces that often experiences land fires with an average burned area of 3 thousand hectares each year. In 2015 and 2019, South Sumatra became the province with the most extensive fire area in Indonesia, reaching 646,298.80 ha in 2015 and 336,798 ha in 2019 (KLHK 2018; KLHK 2020). Ogan Komering Ilir Regency is a regency in South Sumatra Province with the highest fire hazard level and is very prone to forest and land fires (Dinas Kehutanan Provinsi Sumatera Selatan 2016). In the 2015 to 2019 period, Ogan Komering Ilir Regency became the district with the largest burned area and the largest number of hotspots in South Sumatra Province. Even in 2015, the burned land and forest in Ogan Komering Ilir Regency reached 377,333 ha with total hotspots of 16,008 hotspots (Dinas Kehutanan Provinsi Sumatera Selatan 2018), which cause a loss of IDR 53.81 billion (World Bank 2015).

Recurring forest and land fires have sparked the government to enforce the law. Prison sentences of up to 15 years and a fine of IDR 15 billion under Indonesian Law Number 41 of 1999 threaten people who do not comply with the regulation. The prohibition of managing land by burning has affected people's livelihood systems. The use of fires in land clearing for rice plantation and rubber plantation rejuvenation is difficult to leave behind (Nurlia et al. 2018) because it is regarded as the most cost-effective, fastest, and easiest method to clear the land (Irwandi et al. 2016). Therefore, the implementation of forest and land fire policy has significant effects on farmers' livelihood. As the smallest social unit in society, every household must be able to cope with and adapt to the new paradigm by implementing different livelihood strategies that can guarantee their livelihoods, which eventually might affect their livelihood resilience and vulnerability (Abdurrahim 2014).

Resilience is the system's capacity to absorb disturbances and reorganize when changes occur (Walker et al. 2004). Resilience can flexibly face various disturbances and shocks or crises and continue to survive above threatening vulnerabilities. The concept of resilience can help understand the factors that enable communities to protect their livelihoods from the adverse consequences of change (Speranza et al. 2014).

To survive, the community will make maximum use of the resources they have to meet their families' needs. The community will access the capital assets they have to obtain a sustainable livelihood strategy. Livelihood strategy is obtained by combining various assets and access to livelihoods that are owned. Based on the Sustainable Livelihood (SL) approach, farmer households have five livelihood capitals that affect their livelihood resilience. The five capitals are human capital, social capital, physical capital, financial capital, and natural capital (DFID 1999; Ellis 1999; Krantz 2001; Scoones 2015). The five capitals will influence the farmer's household livelihood strategy in the face of various vulnerabilities that occur. This study aims to analyze the livelihood assets that can be owned and accessed by farmer households and to analyze the livelihood strategies of farmer households developed in relation to the livelihood assets they have. 


\section{Materials and Methods}

\subsection{The Study Area}

The research was conducted in Pulu Beruang Village, Tulung Selapan District, and Kayu Labu Village, Pedamaran Timur District, Ogan Komering Ilir (OKI) Regency. Village selection is based on fire vulnerability (occurrence and repetition) and accessibility for research of a village. The research was conducted for 5 (five) months, from February to June 2020.

Geographically, Pulu Beruang Village is located between $3^{\circ} 14^{\prime} 51.93^{\prime \prime}$ to $3^{\circ} 24^{\prime} 29.36$ " South Latitude and from $105^{\circ} 14^{\prime} 56.01^{\prime \prime}$ to $105^{\circ} 25^{\prime} 29.94^{\prime \prime}$ East Longitude, with an area is 6,767 ha. Meanwhile, Kayu Labu Village is geographically located between $3^{\circ} 28^{\prime} 10.36^{\prime \prime}$ to $3^{\circ} 36^{\prime} 51.31^{\prime \prime}$ South Latitude and from $105^{\circ} 11^{\prime} 53.28^{\prime \prime}$ to $105^{\circ} 21^{\prime} 52.27^{\prime \prime}$ East Longitude, with an area of 17,444 ha (Fig. 1). The dominant land use in Pulu Beruang Village is rubber plantations, and land uses in Kayu Labu Village are oil palm plantations and rubber plantations.

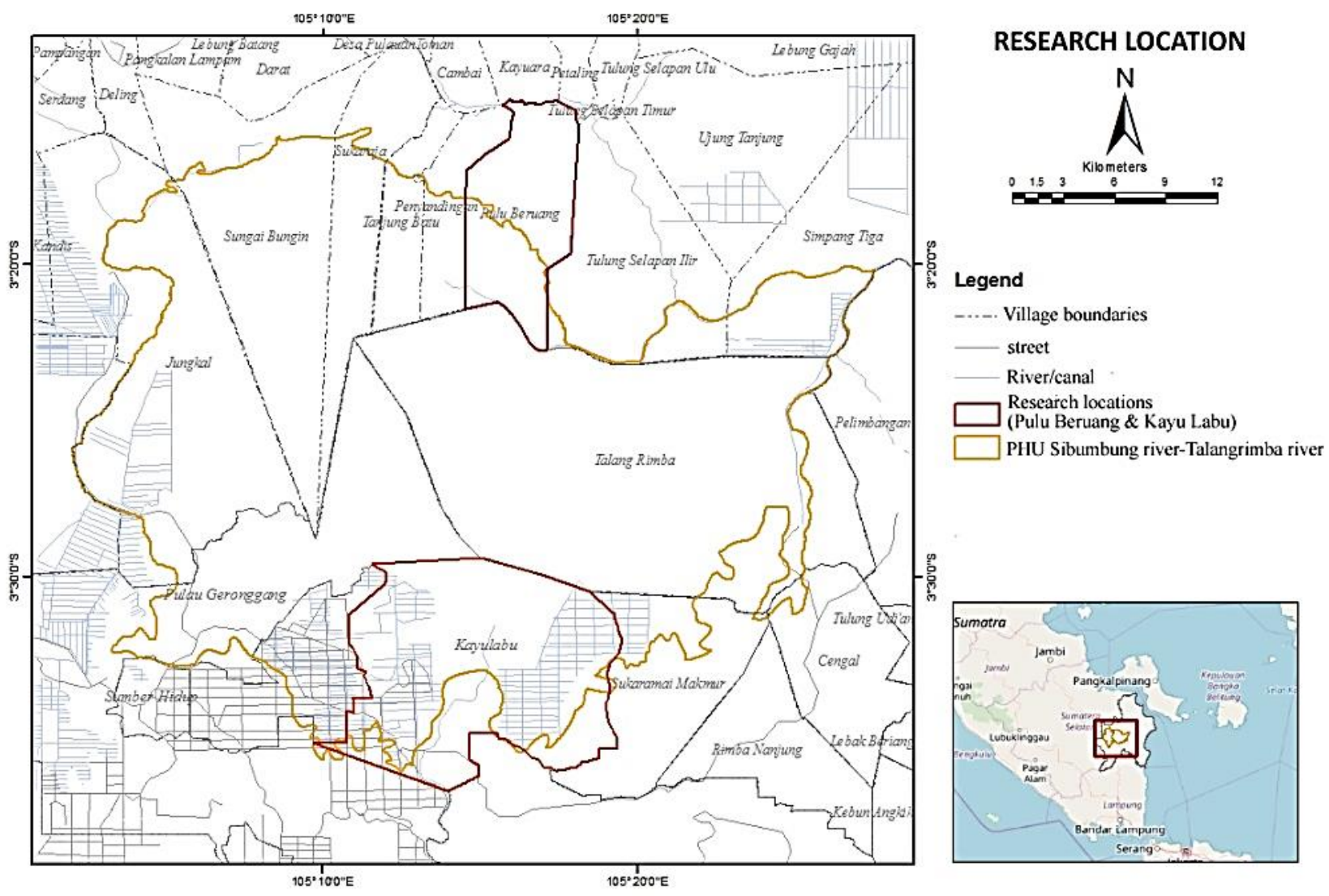

Fig. 1. Map of the research location in Pulu Beruang Village and Kayu Labu Village.

\subsection{Methods}

The research was conducted using a mixed-method (quantitative and qualitative approaches). The mixed approach used is the explanatory sequential mixed approach, as explained by (Cresswell 2016). Both approaches aim to enrich the quantitative data and better understand the social phenomena (Singarimbun 2008). In practice, this approach is carried out using the triangulation principle. According to Neuman (2013), the use of the triangulation approach allows analysis from various points of view and improves analysis accuracy. The application of the triangulation approach in this study was carried out on three aspects of the study, namely: 
1. The research analysis was carried out on three livelihood aspects, namely assets-accessactivities.

2. The data collection unit consists of three different units, namely respondents, informants, and groups.

3. Methods or techniques of data collection were carried out using a triangular approach, namely, interviews, examinations, and observations.

\subsection{Research Population and Sample Respondent}

Respondents in the current study were household-based. The total household in the two villages was 331 households in Pulu Beruang and 240 households in Kayu Labu, consecutively. The number of respondents was determined using a formula of Krejcie and Morgan (1970) as follows:

$$
n=\frac{N \chi^{2} P(1-P)}{(N-1) d^{2}+\chi^{2} P(1-P)}
$$

where $n=$ sample size (respondents), $N=$ population size, $P=$ proportion (opportunity function) of the population $(0.5), d=$ prediction error (error rate) $(10 \%), \chi^{2}=$ chi-squared for degrees of freedom (3.84; assuming 95\% reliability level and 1 degree of freedom).

Based on Krejcie and Morgan (1970) formula, then the number of respondents in Pulu Beruang Village was 75 respondents, and the number of respondents in Kayu Labu Village was 70 respondents.

\subsection{Data Collection and Analysis}

Quantitative data collection was conducted through a household survey using a questionnaire to 75 respondents in Pulu Beruang Village and 70 respondents in Kayu Labu Village. The respondents were determined by simple random sampling without replacement.

Qualitative data collection was carried out through in-depth interviews with household representatives from all groups, village heads, village officials, community leaders, and traditional leaders. Focus Group Discussions (FGD) were conducted to validate the data that heen obtained as well as to deepen and perfect the data previously obtained.

Quantitative data analysis was carried out using scoring with the assumption that the more supportive an element was, the greater the score. The value of each capital asset was the average of the total score of the constituent indicators. To equalize the weight of the calculation and facilitate interpretation, the scoring results were converted into scores on a scale of one to ten (Wijayanti et al. 2016). Qualitative data analysis using a five-phase approach as explained by Yin (2011): (1) compilation, (2) dismantling, (3) reassembly, (4) interpretation, and (5) concluding. The research objectives, variables, operational definitions, indicators, and types of data used in the research are described more detail in Table 1.

\section{Results and Discussion}

\subsection{Socio-Economic Characteristics of the Community}

The social characteristics of the community are information that must be known to obtain an overview of the socio-economic conditions of the community in an area. Socio-economic 
characteristics are needed as initial information to identify research locations to prepare research activities. The socio-economic characteristics of the community in this research can be seen in Table 2.

Table 1. Research objectives, variables, operational definitions, indicators, and types of data

\begin{tabular}{|c|c|c|c|c|}
\hline Objectives & Variables & Operational Definitions & Indicators & $\begin{array}{l}\text { Data } \\
\text { Types }\end{array}$ \\
\hline \multirow{5}{*}{$\begin{array}{l}\text { Respondent } \\
\text { characteristics }\end{array}$} & \multirow{5}{*}{$\begin{array}{l}\text { Respondent } \\
\text { characteristics }\end{array}$} & \multirow{5}{*}{$\begin{array}{l}\text { The diversity profile of } \\
\text { respondents (Soselisa et al. 2013) }\end{array}$} & Age & Ratio \\
\hline & & & Education & Nominal \\
\hline & & & $\begin{array}{l}\text { The origin of a } \\
\text { population }\end{array}$ & Nominal \\
\hline & & & $\begin{array}{l}\text { Number of family } \\
\text { dependents }\end{array}$ & Ratio \\
\hline & & & Income & Ratio \\
\hline \multirow{21}{*}{$\begin{array}{l}\text { Livelihood asset } \\
\text { ownership }\end{array}$} & \multirow[t]{4}{*}{ Human capital } & \multirow{4}{*}{$\begin{array}{l}\text { The ability of a person to gain } \\
\text { better access to their living } \\
\text { conditions (Wijayanti et al. 2016) }\end{array}$} & Education & Ordinal \\
\hline & & & Work experience & Ratio \\
\hline & & & Working productive age & Ratio \\
\hline & & & Health & Ordinal \\
\hline & \multirow[t]{4}{*}{ Financial capital } & \multirow{4}{*}{$\begin{array}{l}\text { Financial sources that can be } \\
\text { used and utilized by the } \\
\text { community in achieving their } \\
\text { livelihood goals, which include } \\
\text { reserves or supplies, either } \\
\text { owned by themselves or financial } \\
\text { institutions as well as in the form } \\
\text { of a regular flow of funds (DFID } \\
\text { 1999) }\end{array}$} & Income & Ratio \\
\hline & & & Savings & Nominal \\
\hline & & & Debt & Nominal \\
\hline & & & Aid & Ordinal \\
\hline & \multirow[t]{4}{*}{ Natural capital } & \multirow{4}{*}{$\begin{array}{l}\text { Capital obtained from nature or } \\
\text { the environment, either } \\
\text { renewable or non-renewable } \\
\text { resources (DFID 1999) }\end{array}$} & Land tenure & Ordinal \\
\hline & & & Water sources & Nominal \\
\hline & & & Fuel & Nominal \\
\hline & & & Environmental services & Ordinal \\
\hline & \multirow[t]{4}{*}{ Physical capital } & \multirow{4}{*}{$\begin{array}{l}\text { Basic infrastructure and other } \\
\text { facilities owned and built to } \\
\text { support community livelihood } \\
\text { processes (Wijayanti et al. 2016) }\end{array}$} & $\begin{array}{l}\text { Facilities and } \\
\text { Infrastructure }\end{array}$ & \multirow{4}{*}{ Ordinal } \\
\hline & & & Transportation & \\
\hline & & & Working tool & \\
\hline & & & Accessibility & \\
\hline & \multirow[t]{5}{*}{ Social capital } & \multirow{5}{*}{$\begin{array}{l}\text { Social resources that are useful } \\
\text { and used by the community to } \\
\text { achieve their livelihood goals } \\
\text { (DFID 1999) }\end{array}$} & Organization & \\
\hline & & & Participation & \\
\hline & & & Mutual cooperation & Ordinal \\
\hline & & & Kinship relations & \\
\hline & & & Social network & \\
\hline \multirow[t]{4}{*}{ Livelihood strategy } & On-farm & \multicolumn{2}{|c|}{$\begin{array}{l}\text { Efforts to increase production yield per unit area through } \\
\text { investment or increase in labor input, or seeking more land } \\
\text { for cultivation (Wijayanti et al. 2016) }\end{array}$} & \\
\hline & $\begin{array}{l}\text { Off-farm } \\
\text { (diversification) }\end{array}$ & \multicolumn{2}{|c|}{$\begin{array}{l}\text { Another alternative to off-farm or non-farm activities as a } \\
\text { means of fulfilling needs when the main livelihood is } \\
\text { deemed not possible to meet household livelihoods } \\
\text { (Wijayanti et al. 2016) }\end{array}$} & Nominal \\
\hline & \multirow[t]{2}{*}{ Migration } & \multirow{2}{*}{$\begin{array}{l}\text { Looking for a living in another } \\
\text { place temporarily or permanently } \\
\text { and changing jobs (Wijayanti et } \\
\text { al. 2016) }\end{array}$} & Permanent Migration & \\
\hline & & & $\begin{array}{l}\text { Circular/Commuting } \\
\text { Migration }\end{array}$ & \\
\hline
\end{tabular}

The average age of the population in the two villages was between 31 and 40 years, which is categorized as productive age. Age affects labor productivity because it is related to physical abilities (Ukkas 2017). This shows that the community is in the top condition in carrying out its activities. 
Table 2. Socio-economic characteristics of the community in Pulu Beruang and Kayu Labu Villages

\begin{tabular}{llrrrr}
\hline \multirow{2}{*}{ Characteristics } & \multicolumn{1}{c}{ Classification } & \multicolumn{2}{c}{ Pulu Beruang } & \multicolumn{2}{c}{ Kayu Labu } \\
\cline { 3 - 6 } & & Freq & Percentage (\%) & Freq & Percentage (\%) \\
\hline Age (years) & $20-30$ & 15 & 20.00 & 9 & 12.86 \\
& $31-40$ & 30 & 40.00 & 28 & 40.00 \\
& $41-50$ & 17 & 22.67 & 14 & 20.00 \\
& $51-60$ & 8 & 10.67 & 11 & 15.71 \\
& $>60$ & 5 & 6.67 & 8 & 11.43 \\
\hline Education & No education & 0 & 0.00 & 8 & 11.43 \\
& Elementary school & 47 & 62.67 & 32 & 45.71 \\
& (SD)/equivalent & & & & \\
& Junior high school & 17 & 22.67 & 22 & 31.43 \\
& (SMP)/equivalent & & & & \\
& Senior high school & 10 & 13.33 & 7 & 10.00 \\
& (SMU)/equivalent & & & & \\
& College & 1 & 1.33 & 1 & 1.43 \\
\hline The origin of a & Non-migrants & 58 & 77.33 & 21 & 30.00 \\
population & Immigrants & 17 & 22.67 & 49 & 70.00 \\
\hline Number of family & $\leq 1$ & 17 & 22.67 & 19 & 27.14 \\
dependents & 2-3 & 45 & 60.00 & 36 & 51.43 \\
(person or individual) & 4-5 & 13 & 17.33 & 14 & 20.00 \\
& $>5$ & 0 & 0.00 & 1 & 1.43 \\
\hline Income & $\leq$ IDR 1,589,800 & 22 & 29.33 & 20 & 28.57 \\
& $>$ IDR 1,589,800 & 53 & 70.67 & 50 & 71.43 \\
\hline Sounyyyy & & & &
\end{tabular}

Source: primary research data.

The average education in both villages was elementary level (SD). Education can affect people's ability to accept innovation. The higher a person's education level, the easier it will be to accept innovations (Slamet 2012).

The origin of the population could be divided into two: migrants and non-migrants. Migrants are people who came from outside the region but currently have settled and are part of the village community, while non-migrants were people who have lived in the village for generations. The results revealed that the two villages showed different social characteristics. Most of the people in Pulu Beruang Village were non-migrants, mainly the Selapan tribe, while in Kayu Labu Village, most of them (70\%) are Javanese. The origin of the population affected the cropping pattern of the community.

The average number of dependents in the two villages was 2-3 people per family. Family dependents can affect not only household expenses but also can be used as unpaid family labor (Sopamena 2019). Family members of a productive age can assist the head of the family in meeting his family's needs.

Poverty is described as a lack of income to meet the basic or minimum necessities of life, namely clothing, food, housing, education, and health (Mubyarto 2004). Based on the district/city poverty indicators in South Sumatra Province, it is known that the poverty line of Ogan Komering Ilir is IDR 1,589,800/household/month (BPS 2020). Current study results showed that most of the people in the two villages (70.67\% in Pulu Beruang and 71.43\% in Kayu Labu Village) lived above 
the poverty line with an income higher than IDR $1,589,800$. However, the average income of the community was still very low, with an average of IDR 2,000,000/people/month.

\subsection{Farmers Livelihood Assets}

Livelihood assets studied in current research included material and social resources that humans use to carry out their livelihoods. Five forms of capital or so-called livelihood assets for livelihoods are human capital, financial capital and substitutes, natural capital, physical capital, and social capital (DFID 1999; Ellis 1999).

\subsubsection{Human capital}

Human capital is capital that is owned or exists in humans (DFID 1999). Human capital shows a person's ability to gain better access to their living conditions (Wijayanti et al. 2016). Human capital is the principal capital in livelihood assets needed to determine the community's livelihood strategies and an essential component in managing four other livelihood assets. The research result revealed that Pulu Beruang Village showed a greater human capital score than Kayu Labu Village (Table 3).

Table 3. Human capital score

\begin{tabular}{clcc}
\hline \multirow{2}{*}{ No } & & \multicolumn{2}{c}{ Score } \\
\cline { 3 - 4 } & & Pulu Beruang & Kayu Labu \\
\hline 1 & Education & 5.57 & 4.89 \\
2 & Work experience & 4.19 & 2.83 \\
3 & Working productive age & 6.67 & 7.38 \\
4 & Health & 9.20 & 9.29 \\
& Total & 25.62 & 24.38 \\
& Average & 6.41 & 6.10 \\
\hline
\end{tabular}

The average level of education in both villages was elementary school level, causing knowledge on and awareness of forest and land fires was still low. The level and quality of education determine the quality of Human Resources (Aini et al. 2018). Education affects people's knowledge and ability to accept innovation. Knowledge can influence people's perceptions in determining their household livelihood strategies.

Work experience relates to the length of time the community involved in work activities. The work experience score in Pulu Beruang Village was higher than that in Kayu Labu Village because most of the community has carried out their activities for generations, such as planting rubber and fishing. Most of the people in Kayu Labu Village were transmigrants who have just started farming in the village. Although most people already had experience in their area of origin, the different natural conditions where most of the land was peatland required them to adapt to current land conditions. The community in Kayu Labu Village uses peatland for both vegetable and fruit tree cultivation.

The labor in Kayu Labu Village had a greater score than that in Pulu Beruang Village. It was found that the workforces in Kayu Labu Village consisted of three people per family, while that was in Pulu Beruang Village consisted of two people per family. Labor assistance that comes from families can reduce labor costs because it is not calculated as expenses. This is in accordance with 
the research results of Wijayanti et al. (2016), which stated that the more the number of productive family members who helped the farming business, the lower labor costs.

The health conditions of the people in the two villages were classified as very good, where most of the people in both locations stated that they were in good health and did not have dangerous diseases. This was also confirmed by health workers who were in both villages.

\subsubsection{Financial capital}

Financial capital is capital that can be used to earn a living for a household. DFID (1999) stated that financial capital is financial resources that the community can use and utilize in achieving their livelihood goals, which include reserves or supplies, either owned by themselves or financial institutions, and in the form of a regular flow of funds.

The score of financial capital in Pulu Beruang Village was higher than that in Kayu Labu Village. The variable with the highest scores included income and aid variables (Table 4). The income in the two villages ranges between IDR 1,000,000 up to IDR 2,000,000, with the primary source of income for the community was farming, especially rubber, oil palm, and vegetables.

Table 4. Financial capital score

\begin{tabular}{clccc}
\hline \multirow{2}{*}{ No } & & \multirow{2}{*}{ Indicator } & \multicolumn{2}{c}{ Score } \\
\cline { 3 - 4 } & & Income & 6.72 & Kayu Labu \\
\hline 2 & Savings & 5.00 & 4.74 \\
3 & Debt & 5.87 & 5.27 \\
4 & Aid & 7.13 & 6.07 \\
& Total & 24.72 & 5.43 \\
& Average & 6.18 & 21.81 \\
\hline
\end{tabular}

The people in Pulu Beruang Village had more diverse jobs than those in Kayu Labu Village. In Kayu Labu, besides agriculture, the community's primary source of income included fisheries and purun crafts. Meanwhile, in Pulu Beruang Village, besides agriculture, the community's income sources consisted of trading, swallow nests business, fishing, plantations, and mining. The more diverse sources of income in Pulu Beruang Village caused the community's income in Pulu Beruang Village to have a higher score than that of Kayu Labu Village.

Communities in both villages did not realize the importance of saving for urgent financial capital in the future. The people in Pulu Beruang Village were not used to saving either in the form of money, gold, or dry rubber. If there was an urgent need, they preferred to borrow financial capital from the rubber collectors. In return, they have to pay out the loan in the form of rubber products. In contrast, the people in Kayu Labu Village have started saving money and dry rubber. Saving in the form of dry rubber for the community was preferred because it was easier and faster to sell.

The community in both villages are still accustomed to borrowing money from rubber sap collectors for daily needs, farming capital, and urgent needs. The debt would be paid out by reducing the selling price of rubber. The community's habit of being in debt caused the community to have no bargaining position in determining the selling price of rubber. Community dependence on debt causes them to accept whatever the selling price of rubber. 
The financial aid received by the community to date comes from government aid. Government financial aid widely received by the community in Pulu Beruang Village was called "Program Keluarga Harapan" which provided social aid to the poor for health and education. In addition, the South Sumatra Partnership Project Manager Unit (PMU) built ten wells that functioned as water sources mainly during the dry season. The assistance provided in Kayu Labu Village was how to support agricultural activities, such as Rice Product Facilities, the development of 1,100 ha rice fields, support for revitalizing livestock, and rewetting.

\subsubsection{Natural capital}

Nature is an important factor in farmer households' livelihood capital, considering that the community in the two villages are farmers who rely on natural capital for their livelihood. Land tenure is the variable that plays a crucial role in natural capital. To be able to run a business, the most basic natural capital that a household must have is a piece of land. The term land tenure is used based on the theory of the concept of "access" (Ribot and Peluso 2003), where access is the ability to get benefits from objects, in this case, the island. In accordance with this view, land tenure is defined as access to land to be managed, which can be obtained by owning and rent, pawning, or profit-sharing. In this research, natural capital is land tenure, water sources, fuels, and environmental services, and their scores, as presented in Table $\mathbf{5}$.

Table 5. Natural capital score

\begin{tabular}{clcc}
\hline \multirow{2}{*}{ No } & \multicolumn{1}{c}{ Indicator } & Score & \\
\cline { 3 - 4 } & & Pulu Beruang & Kayu Labu \\
\hline 1 & Land tenure & 3.47 & 3.57 \\
2 & Water sources & 7.04 & 4.94 \\
3 & Fuel & 3.51 & 6.33 \\
4 & Environmental services & 5.10 & 6.43 \\
& Total & 19.12 & 21.28 \\
& Average & 4.78 & 5.32 \\
\hline
\end{tabular}

Farmers in both villages have an average of 2 ha of land with ownership right certificate issued either at the village level or at the sub-district level. The community could own the land because they bought or received an inheritance from their parents. In terms of agricultural water sources, farmers in Pulu Beruang Village used swallow wells for irrigation, while those in Kayu Labu Village still relied on precipitation (rain-fed agriculture). In addition, some farmers also relied on canals and creeks as water sources for their agriculture.

Nowadays, almost all people have been using gas for cooking. Very few people still used wood fuel in their daily lives. Only on certain occasions, such as big celebrations, people use wood fuel to cook. The shift in the fuel sources might also be related to the fact that wood fuels have been limited due to deforestation.

The utilization of environmental services in the two villages is only limited to the use of groundwater. There were 8 units of drilled wells in Pulu Beeruang, built using financial support from the government called Village Fund. Meanwhile, there were 9 drilled in Kayu Labu. However, most people widely used swallow wells for their daily consumption. Usually, people with fairly good financial conditions own swallow wells or drilled wells privately. 


\subsubsection{Physical capital}

Physical capital is basic infrastructure and other facilities built to support the community's livelihood process (Wijayanti et al. 2016). Physical capital consists of two categories, namely (1) basic physical infrastructure that can meet basic needs and make households more productive, and (2) objects and equipment that can be used by households to produce (productive assets) or increase work productivity (Abdurrahim 2014). In this research, the basic physical infrastructure consisted of facilities and infrastructure, while the productive assets consisted of work tools and accessibility (Table 6).

Table 6. Physical capital score

\begin{tabular}{clcc}
\hline \multirow{2}{*}{ No } & \multicolumn{1}{c}{ Indicator } & Score \\
\cline { 3 - 4 } & & Pulu Beruang & Kayu Labu \\
\hline 1 & Facilities and Infrastructure & 8.37 & 8.32 \\
2 & Transportation & 7.20 & 7.18 \\
3 & Working tool & 9.53 & 9.14 \\
4 & Accessibility & 7.49 & 6.93 \\
& Total & 32.59 & 31.57 \\
& Average & 8.15 & 7.89 \\
\hline
\end{tabular}

The most basic physical capitals that must be owned by a household are a house and household assets. A house to live in is a basic necessity for a society. In general, most of the houses in the two villages (61.3\% in Pulu Beruang Village and $80.0 \%$ in Kayu Labu Village) were wooden houses. These wooden houses were characterized by local architecture (Ogan Komering Ilir) and belonged to the indigenous people. People usually used the lower part of the house as a warehouse, and some even used it as a small shop. Unlike the migrants such as those in the Hamlet (Dusun) 5 Senasih Mulya, Kayu Labu Village, the houses were one-story houses with most of the building materials being wood, especially for the walls. The difference in the shape of the house was due to cultural differences in each hamlet. Most of the house ownership was personally owned by farmers, and the rest were either inherited from the parents, rent, or family house.

The means of transportation owned by most people in the two villages were motorcycles to support their mobility. Some considered expensive assets, such as cars and laptops, were only owned by a small proportion of households, especially those with high incomes. In Kayu Labu Village, electronics goods ownership was still limited because electricity was not available, especially in the Hamlet 5 Senasih Mulya.

Working tools are one of the tools needed to support the implementation of community livelihood strategies. Most community members have fully realized that their activities to fulfill their livelihoods would be hampered without being supported by appropriate and enough working tools. Unfortunately, not all working tools were personally owned by the community, especially heavy equipment such as a tractor. Therefore, the Local Office of Agriculture provided heavy equipment, which was managed by the village government.

\subsubsection{Social capital}

Social resources are generally intangible and are not easy to measure, but they are beneficial to society (DFID 1999). Amalia et al. (2015) defined social capital as the availability of networks that can be used to increase the resilience of a community. The social capital assessed in this 
research was the existing organization, such as village institutions and farmer groups, participation, cooperation, kinship, and social networks (Table 7). Kayu Labu Village had a higher score (7.63) on social capital than Pulu Beruang Village (7.24).

Table 7. Social capital composing variables and scores

\begin{tabular}{clcc}
\hline \multirow{2}{*}{ No } & \multicolumn{1}{c}{ Indicator } & \multicolumn{2}{c}{ Score } \\
\cline { 3 - 4 } & & Pulu Beruang & Kayu Labu \\
\hline 1 & Organization & 7.47 & 6.53 \\
2 & Participation & 7.33 & 7.43 \\
3 & Mutual cooperation & 5.60 & 7.07 \\
4 & Kinship & 9.10 & 9.07 \\
5 & Social network & 8.67 & 6.08 \\
& Total & 38.17 & 36.19 \\
& Average & 7.63 & 7.24 \\
\hline
\end{tabular}

The community membership and activeness in the existing institutions in Pulu Beruang Village were still low. An organization related to the new agricultural sector was formed in 2019, namely the Puber Mandiri Pangan community group. On the other hand, farmer groups were not found in Pulu Beruang Village. Busyness at work and physical conditions (fatigue) made people unable to be active in organizations.

In contrast, a higher score (7.43) of membership and level of community participation in Kayu Labu Village indicated a high activity and participation of the community in the existing organization, especially in farmer groups. The main reason was because the farmers could benefit from the existence of farmer groups, which eventually would improve community resilience to disturbances.

The current study also revealed that mutual cooperation and kinship showed a high score in both villages (Table 7). Social habits of society, such as religious ceremonies, wedding ceremonies, were still very strong and well preserved in the community. In addition, the high score of kinship (9.10 in Pulu Beruang and 9.07 in Kayu Labu) showed that the community in both villages also still had very strong social ties.

The social networks assessed in this research focused on the use of cell phones and internet. The results showed that most people had used cell phones in their daily lives. Apart from being a means of communication, cell phones are also assets to support their livelihood activities, such as selling agricultural products and communicating between traders and co-workers. However, there were still people who had not used cellphones yet, especially those in the Hamlet 5 Senasih Mulya, because they were still constrained by the availability of cell phone networks and signals.

The internet had been widely used in Pulu Beruang Village. People used it for social media and searching for information from outside. Although far from the district city center, Pulu Beruang Village was easier to reach and had better access than Kayu Labu Village. In contrast, the use of internet in Kayu Labu Village was still limited as the available networks and signals were lack.

\subsubsection{Livelihood assets owned and can be accessed by farmer households}

The score of household livelihood assets in each village varied depending on the scores of human capital, financial capital, natural capital, physical capital, and social capital. The results showed that Pulu Beruang Village had a higher total score of livelihood assets (33.15) than Kayu 
Labu Village (32.00) (Table 8). The current study showed that households in Pulu Beruang Village had higher scores on the human capital, financial capital, physical capital, and social capital. In comparison, those in Kayu Labu Village showed higher natural capital scores.

Table 8. Asset score of household livelihoods in Pulu Beruang and Kayu Labu Villages

\begin{tabular}{clcc}
\hline \multirow{2}{*}{ No } & \multicolumn{1}{c}{ Livelihood Capital } & Score \\
\cline { 3 - 4 } & & 6.41 & Kayu Labu \\
\hline 1 & Human capital & 6.18 & 6.10 \\
2 & Financial capital & 4.78 & 5.38 \\
3 & Natural capital & 8.15 & 5.32 \\
4 & Physical capital & 7.63 & 7.97 \\
5 & Social capital & 33.15 & 7.24 \\
& Total & & 32.00 \\
\hline
\end{tabular}

The relationship and linkages of each capital in both villages were then analyzed, and the asset pentagons were presented in Fig. 2. The asset pentagon showed that households in the two villages had different patterns of linkages among capital assets. The fact that human capital and financial capital in Pulu Beruang Village had a greater score than those in Kayu Labu Village showed that livelihood strategies in Pulu Beruang Village were more diverse than those in Kayu Labu.

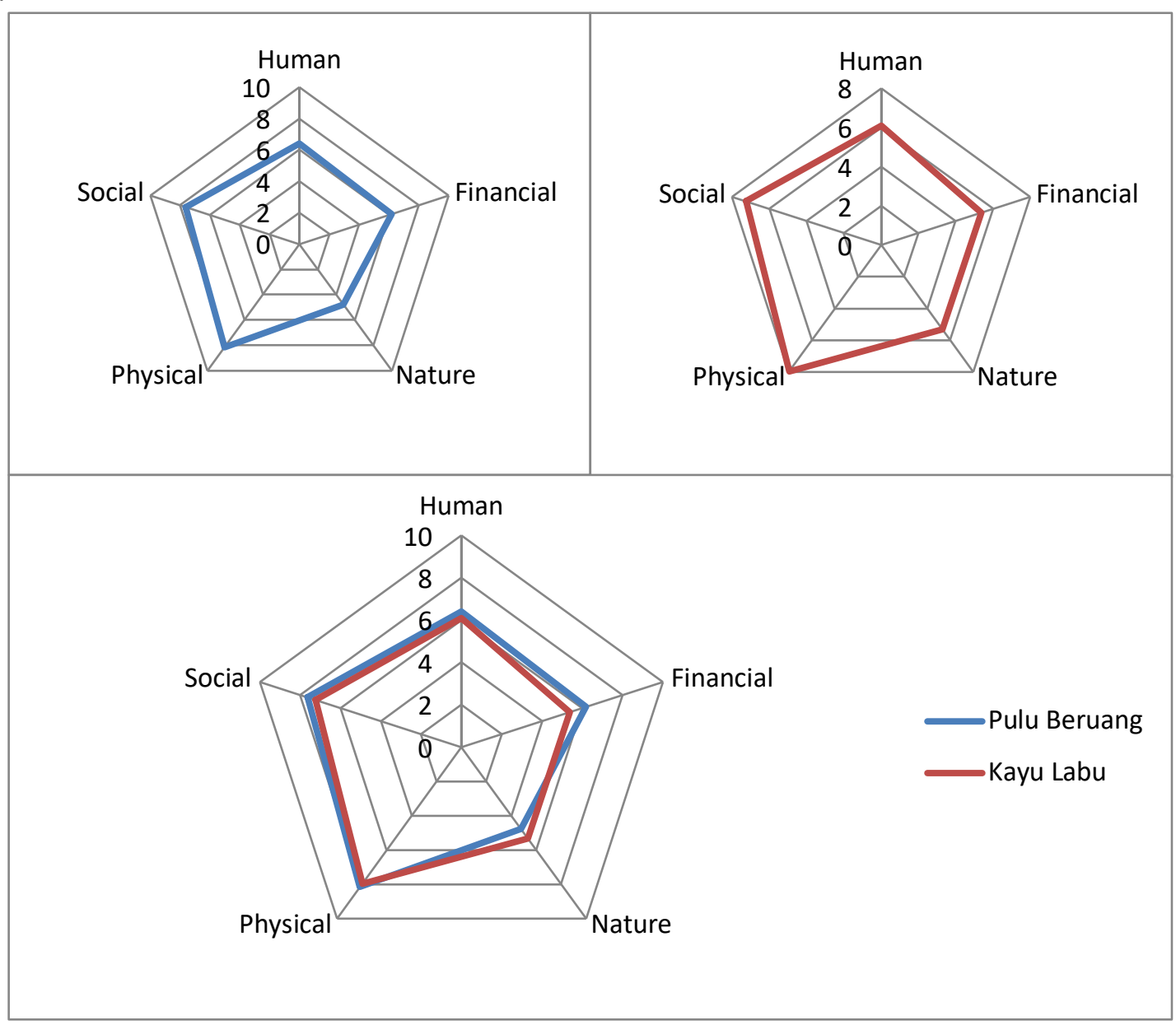

Fig. 2. The pentagon assets in Pulu Beruang Village and Kayu Labu Village. 
Households in Kayu Labu Village had a high score on the natural capital. It showed that people in Kayu Labu Village had a high dependence on natural capital. They used the available land (mineral and peat) for farming. In addition, people were also engaged in both fisheries and purun crafts.

The fact that the physical capital and social capital scores in the two villages were not much different showed that these two capitals exerted similar effects on community resilience to disturbances. Having different strengths of dependence on each capital and different strengths of interlinkages among capitals encouraged communities to combine their assets to develop livelihood strategies to strengthen their resilience to disruptions.

\subsection{Farmers Household Livelihood Strategy Analysis}

Livelihood strategy analysis was carried out based on the analysis of assets and access to livelihoods discussed in the previous chapter. According to Ellis (1999), livelihood strategy consists of various livelihood activities in the community. Each livelihood strategy is implemented through multiple livelihood activities by every household member who can work. Chambers and Conway (1991) argued that every household from all social strata must strive to face and adapt to ecological vulnerabilities by maintaining or increasing the capacity of their livelihood assets and combining their own and accessible livelihood assets into various forms of livelihood strategies to sustain their livelihoods.

The analysis of farmer household livelihood strategies in this research used theory-based grouping described by Scoones (2015). The household livelihood strategies were classified into three groups, namely agriculture, diversification of non-agricultural livelihoods, and migration. The results are presented in Table 9.

Table 9. The scores of livelihood strategies in Pulu Beruang and Kayu Labu Villages

\begin{tabular}{lcc}
\hline \multirow{2}{*}{ Livelihood Strategy } & \multicolumn{2}{c}{ Score } \\
\cline { 2 - 3 } & Pulu Beruang & Kayu Labu \\
\hline On-farm (agriculture) & 61.33 & 74.29 \\
Off-farm (diversification) & 26.67 & 25.71 \\
Migration & 12.00 & 0.00 \\
\hline
\end{tabular}

\subsubsection{Agricultural sector}

Agriculture was the primary household livelihood strategy for the community in both villages. The community involved in the agricultural sector could be divided into two groups, namely groups of people who cultivated their land and groups of people who cultivated other people's land called agricultural laborers. Community groups with the status of agricultural laborers earn a profit-sharing system or wages.

The main livelihood strategy in the agricultural sector in both villages was to develop rubber plantations. Rubber was the community's main choice because it has been planted for generations. Easy maintenance and the relatively fast production made people choose rubber as their main crop to support their livelihood strategies. The tapped latex is sold once a week for IDR 4,500 to IDR $6,500 / \mathrm{kg}$. According to the community, the rubber's selling price has been decreasing every year. Unfortunately, people did not have a bargaining position in determining the price. It occurred because most of the community has already been tied up in debt with collectors. Additionally, the quality of latex was still low because it contained impurities. The main difference between rubber 
farmers in Pulu Beruang Village and Kayu Labu Village was lying in the type of land being cultivated. Most of the rubber trees in Pulu Beruang Village has been planted on mineral soils, while those in Kayu Labu Village has been on peat soils.

Apart from rubber, the community has also planted oil palm since 2013. The oil palm farmers were members of existing palm oil companies. The income of oil palm farmers was dependent on the oil palm farmer cooperatives. The income earned from oil palm plantations was uncertain and could not be expected to meet daily needs.

Before land clearing by burning was prohibited, the community cultivated rice using sonor, especially during the dry season. However, sonor practices in Pulu Beruang Village have been discontinued since 2015, along with the implementation of a no-burning policy. Unlike in Pulu Beruang Village, the people in Kayu Labu Village are still cultivating paddy. Kayu Labu Village was chosen as a location for a new paddy field preparation program. It covered an area of 1,100 ha spreading over Hamlet 5 Senasih Mulya covering an area of 500 ha, and main hamlets (Hamlet 1 and Hamlet 2), covering an area of 600 ha.

The no-burning policy has affected the community's livelihood strategies, especially in the agricultural sector. Besides being unable to cultivate sonor rice in the dry season, the community also could not carry out land clearing and rejuvenate rubber trees because burning has been regarded as the easiest dan a cost-effective method of land clearing (Irwandi et al., 2016).

The fact that the implementation of a no-burning policy was not accompanied by any alternative land-clearing methods had disappointed communities. Therefore, some communities still practiced burning in land management. To avoid hotspot detection, the burning was carried out gradually where the plant biomasses were piled, called "cumpuan", scattering over several places in their agricultural fields. Usually, burning was carried out in the evening when the air temperature was relatively low, so it was relatively easy to control. One burning session was carried out on a maximum area of 0.25 ha. In addition, the community also prepared firebreaks before burning.

People in Pulu Beruang Village also stopped burning and temporarily suspended planting then adopted other strategies for their living. Meanwhile, people in Kayu Labu Village planted rubber, oil palm, and paddy. The government has supported land preparation through the District Agricultural Office who provided tractors. However, not all locations, especially those in remote areas, could be reached by tractors.

\subsubsection{Non-agricultural diversification}

Non-agricultural diversification is another alternative to agricultural activities as a means of fulfilling needs when the main livelihood is constrained to be able to fulfill household livelihoods (Wijayanti et al. 2016). The livelihood strategies that are mostly used in this group are in the fields of trade, fisheries, purun crafts, and swallow's nest business.

\subsubsection{Trading}

Trading is one of the livelihood strategies that were mostly practiced in Pulu Beruang and Kayu Labu Villages. Activities in the trade sector consisted of grocery stores and food stalls. Most houses in Pulu Beruang Village were stilt houses, enabling people to adopt trading as an alternative strategy for livelihood. The stilt houses allow people to use the ground floor as a shop and the second floor to live. However, income from trading activities was uncertain. The profit obtained 
from trading activities ranged from IDR 200,000 up to IDR 800,000/month. Income from trading contributed 10 to $20 \%$ of total family income (IDR 2,000,000/month). Although the profit from trading was not so much, the merchandise could be used for daily necessities.

Apart from stalls, some people also act as latex collectors (rubber collectors or tokeh karet). Sometimes rubber traders have to compete because there can be several rubber traders in one village. Rubber traders played important roles in determining the price of rubber. On the other hand, rubber farmers had no choice but to sell their rubber to certain rubber traders because they were already tied to loans to these rubber traders.

\subsubsection{Fishery}

The fishery sector was a livelihood strategy widely adopted by the community in Kayu Labu Village, especially those in Hamlet 1 and Hamlet 2 . The community caught fish in the rivers in the peat hydrological unit (PHU) area of Sibumbung River - Talangrimba River. Some common fish widely available in rivers included catfish, snakehead fish, betok, toman, and bujuk. However, catching had become more difficult lately because the peat area had been converted into plantation areas. The catch was usually sold fresh for a price ranging from IDR 10,000 to IDR 20,000/kg. When fishing was the primary livelihood strategy, the average catch of fisherman in Kayu Labu Village was around $30 \mathrm{~kg} /$ week. In contrast, when it was a side job, the catch was only 20 to 40 $\mathrm{kg} /$ month. As a side job, fishing contributed 10 to $20 \%$ of total family income (IDR 2,000,000/month). Apart from fresh fish, the people in Kayu Labu Village have started working on the downstream fishery industry, such as smoked fish, salted fish, and processed products such as kemplang. The downstream industry in the fisheries sector has a high potential to be further developed. Unlike Kayu Labu Village, the fishery sector was a side job for the community in Pulu beruang and carried out by a small community. Fishing in Pulu Beruang Village was usually carried out in the oil palm plantation area. Only women were allowed to fish in the plantation area during the dry season because it was feared that men's smoking and negligence would cause fires. As a side job, fishing was usually carried out after the community has finished their main job, tapping rubber trees. The catch was only 10 to $20 \mathrm{~kg} / \mathrm{month}$, which was usually for their consumption. Part of the catch (maximum of $10 \mathrm{~kg} / \mathrm{month}$ ) was also for sales, contributing to about $5 \%$ of total household income (IDR 2,000,000/month).

In the past, Pulu Beruang Village had a river that could be used as a transportation route that supported community income from the forestry sector. However, dredging conducted in the early 2000s had caused the river to dry up because the dredging had widened the river. It also caused the water in the swamp areas in Pulu Beruang to dry up quickly when the dry season came. This drying has also been exacerbated by the conversion of peatland into plantations in 2012 .

\subsubsection{Purun Craft}

Purun is a typical peat swamp plant that has a high economic score (Giesen 2015). Purun is found in areas that are dominated by peatlands. Purun can be processed into various kinds of handicraft products such as mats, baskets, and handbags. In Kayu Labu Village, many women do purun crafts to help their household income. The price of purun crafts varies depending on the type of purun used and the type of product produced. There are two types of purun used by the community in Kayu Labu Village: purun sabal and purun halus. The difference lies in the size of 
the purun. Purun halus is smaller but longer and more durable than purun sabal. The handicrafts made from purun halus have a higher score than purun sabal.

The type of product that is mostly produced by the community in Kayu Labu Village is a mat. The mats' price ranges from IDR 15,000 up to IDR 50,000 for each sheet, depending on the type of purun used and the number of colors used. The purun halus mat has a higher price than the purun sabal mat due to the longer weaving process. The mat from purun halus is softer so that the mat can be folded into small folds, while the purun sabal mat is stiffer so that the mat can only be rolled.

People prefer to make white purun mats than color purun mats because the manufacturing process is faster. Three white purun mats can be made in one day, while one color purun mat can take up to one week to complete. The drying process is two times, and the coloring process takes a long time to dry the purun mats because one drying takes two to three days to reach a completely dry purun condition.

Marketing of purun mats is only done at the local level. Purun mat buyers are local people who do not have time to make their purun mats due to other activities such as opening a shop or trading, and other people who do not have the skills to make mats. Besides being sold directly, purun mats can also be used as a medium of exchange for daily necessities. People can buy their needs and pay in installments with the purun mats they make.

The raw material for purun mats is obtained directly by the community from peat swamp areas or oil palm planting routes. For one harvest in one day, people can take up to ten bundles of purun. Although purun is harvested almost every day, people are not worried about the extinction of purun because purun is a fast-growing plant. For people who cannot take purun directly, they obtain raw materials by buying. One purun bundle can be purchased for IDR 8,000, and in two bundles, people can make five white purun mat.

Handbag is one of the purun handicraft products, but the community very rarely makes it. This is because not all purun craftsmen can make handbags. The marketing of handbags is not as easy as marketing purun mats because generally, handbag marketing is carried out outside the village. The community can sell up to 10 purun mats per month with an average sale of purun mats is IDR $15,000 /$ sheet, then the income related to purun mats only reach IDR $150,000 /$ month or contributes to people's income by $7.5 \%$ every month. There needs to be assistance for the community related to marketing related to purun crafts to increase productivity and increase the selling price of purun handicrafts.

Based on field observations, the potential for purun was also found in Pulu Beruang Village. However, this potential has decreased due to oil palm plantations. There has not been much use of purun in Pulu Beruang Village because of the lack of community knowledge about purun crafts.

\subsubsection{Swallow's nest}

Swallow's nest is a type of livelihood strategy that is currently being developed in Pulu Beruang Village. The development of swallow's nests business has begun to be carried out by people with middle to upper financial. To develop a swallow's nest business, the community requires much initial capital, especially to build a swallow house and accessories. The initial investment needed to build a swallow house is about IDR 50 million.

Generally, swallow will start to produce within six months after the swallow house is built, but the results will not be maximum. The maximum results will only be obtained after the second 
year when the swallow nest is already in a stable condition. Swallow's nest price varies depending on the quality. The more perfect the shape and the cleaner the nests, the higher the price. A good quality nest would cost IDR $15,000,000 / \mathrm{kg}$, while the low quality (broken and mixed swallow nests) would cost IDR $8,000,000$ to IDR $10,000,000 / \mathrm{kg}$. Swallow productivity will increase in the rainy season from December to March and decrease in the dry season.

\subsubsection{Migration}

Migration is the last strategy carried out by the community after the agricultural strategy, and diversification strategy cannot be implemented. Migration consists of two types, namely circular migration and permanent migration. Circular migration is dynamic mobility in search of employment by leaving the village (trips of more than 30 minutes or more than $15 \mathrm{~km}$ ), while permanent migration is moving permanently (Wijayanti et al. 2016).

The migration strategy was only found in Pulu Beruang Village (18.67\%), where the community worked as plantation workers and worked in mining in Bangka. Whereas in Kayu Labu Village, only very few people had a migration strategy to work on plantations around the village. Even in this research, none of the respondents were found to have implemented the migration strategy as their livelihood strategy.

\section{Conclusions}

Pulu Beruang Village had greater scores on the human capital and financial capital. In comparison, Desa Kayu Kabu had a greater score on the natural capital. The scores on both physical capital and social capital in the two villages were different significantly. Livelihood assets owned by the community influenced their household livelihood strategies. The livelihood strategy of households in Pulu Beruang Village relied more on human and financial capital. In addition to the agricultural sector, they also diversified the non-agricultural sector for their livelihood strategy, especially in the swallow nest business. Meanwhile, households in Kayu Labu relied more on their natural capital, especially on the agricultural sector, such as fisheries and purun crafts.

\section{References}

Abdurrahim, A.Y. 2014. Kerentanan Ekologi dan Strategi Penghidupan Rumah Tangga Petani di Pantai Utara Indramayu. Thesis. Institut Pertanian Bogor.

Aini, E.N., Isnaini, I., Sukamti, S., and Amalia, L.N. 2018. Pengaruh Tingkat Pendidikan terhadap Tingkat Kesejahteraan Masyarakat di Kelurahan Kesatrian Kota Malang. Technomedia Journal 3(1): 58-72. DOI: 10.33050/tmj.v3i1.333

Akbar, A. 2016. Studi Kearifan Lokal Penggunaan Api Persiapan Lahan: Studi Kasus di Hutan Mawas, Kalimantan Tengah. Jurnal Penelitian Sosial dan Ekonomi Kehutanan 8(3): 211230. DOI: $10.20886 /$ jsek.2011.8.3.211-230

Amalia, R., Dharmawan, A.H., and Putri, E.I.K. 2015. Landscape Ecological Changes and Farm Household Livelihoods Resilience around Forest in East Kalimantan. Sodality: Jurnal Sosiologi Pedesaan 3(3): 121-127. DOI: 10.22500/sodality.v3i3.10643

BNPB. 2014. National Disaster Management Plan (Rencana Nasional Penanggulangan Bencana 2015-2019). Jakarta.

BPS. 2020. Garis kemiskinan Kabupaten Ogan Komering Ilir. Badan Pusat Statistik Kabupaten 
Ogan Komering Ilir <https://okikab.bps.go.id/site/resultTab>.

Budiningsih, K. 2017. Implementasi Kebijakan Pengendalian Kebakaran Hutan dan Lahan di Provinsi Sumatera Selatan. Jurnal Analisis Kebijakan Kehutanan 14(2): 165-186. DOI: 10.20886/jakk.2017.14.2.165-186

Cahyono, S.A., Warsito, S.P., Andayani, W., and Darwanto, D.H. 2015. Factors Affecting Forest Fire in Indonesia and Policy Implication. Jurnal Sylva Lestari 3(1): 103-12. DOI: 10.23960/js113103-112

Chambers, R., and Conway, G.R. 1991. Sustainable Rural Livelihoods: Practical Concepts for the 21st Century. IDS Discussion Paper 296.

Cresswell, J.W. 2016. Research Design Pendekatan Metode Kualitatif, Kuantitatif dan Campuran. Pustaka Pelajar, Yogyakarta.

DFID. 1999. Sustainable Livelihoods Guidance Sheets, section 2.1. Department for International Development (DFID). Department for International Development DFID, Victoria Street, London. DOI: $10.1002 / \mathrm{smj}$

Dinas Kehutanan Provinsi Sumatera Selatan. 2016. Laporan dan Modul Teknis Peta Rawan Kebakaran Hutan dan Lahan di Provinsi Sumatera Selatan Tahun 2015. Dokumen Standar Operasional Prosedur (SOP) untuk Pelaksanaan dan Pengelolaan Jaringan Data Spasial Kehutanan (JDSK) di Provinsi Sumatera Selatan. GIZ Biodiversity and Climate Change (BIOCLIME), Palembang.

Dinas Kehutanan Provinsi Sumatera Selatan. 2018. Perbandingan Karhula dan Hotspot Provinsi Sumatera Selatan. Palembang.

Ellis, F. 1999. Rural Livelihood Diversity in Developing Countries: Evidence and Policy Implications. Overseas Development Institute, London (40).

Giesen, W. 2015. Utilising Non-Timber Forest Products to Conserve Indonesia's Peat Swamp Forests and Reduce Carbon Emissions. Journal of Indonesian Natural History 3(2): 69-72.

Irwandi, Jumani, and Ismail, B. 2016. Upaya Penanggulangan Kebakaran Hutan dan Lahan di Desa Purwajaya Kecamatan Loa Janan Kabupaten Kutai Kartanegara Kalimantan Timur. Jurnal AGRIFOR 15: 201-210. DOI: 10.31293/af.v15i2.2076

KLHK. 2018. Rekapitulasi Luas Kebakaran Hutan dan Lahan (Ha) Per Provinsi Di Indonesia Tahun 2011-2018. SiPongi - Karhutla Monitoring Sistem Jakarta. DOI: 10.1103/PhysRevB.65.020504

KLHK. 2020. Rekapitulasi Luas Kebakaran Hutan dan Lahan (ha) di Indonesia Tahun 20152020. Jakarta.

Krantz, L. 2001. The Sustainable Livelihood Approach to Poverty Reduction - An Introduction. Swedish International Development Cooperation Agency, Division for Policy and SocioEconomic Analysis.

Krejcie, R.V., and Morgan, D.W. 1970. Determining Sample Size for Research Activities. Educational and Psychological Measurement 30(3): 607-610. DOI: 10.1261/rna.2763111

Mubyarto. 2004. Menuju Sistem Ekonomi Pancasila : Jurnal Ekonomi dan Bisnis Indonesia.

Neuman, W.L. 2013. Metodologi Penelitian Sosial: Pendekatakan Kualitatif dan Kuantitatif. PT. Indeks, Jakarta.

Nurlia, A., Waluyo, E.A., and Martin, E. 2018. Efektivitas Kebijakan Pembukaan Lahan Tanpa Bakar dalam Mengurangi Kejadian Kebakaran di Lahan Gambut (Kasus di Rengas Merah, Kabupaten OKI, Sumatera Selatan). in: Merawat Asa Restorasi Gambut, Mencegah Kebakaran dan Peningkatan Kesejahteraan Masyarakat Balai Penelitian dan 
Pengembangan Lingkungan Hidup dan Kehutanan Palembang, Palembanng.

Ribot, J.C., and Peluso, N.L. 2003. A Theory of Access. Rural Sociology 68(2): 153-181. DOI: 10.1111/j.1549-0831.2003.tb00133.x

Scoones, I. 2015. Sustainable Livelihoods and Rural Development. Practical Action Publishing and Winnipeg, UK.

Singarimbun, M. 2008. Metode Penelitian Survei. (M. Singarimbun and S. Effendi, eds.) LP3ES, Jakarta.

Slamet, Y. 2012. Konsep-Konsep Dasar Partisipasi Sosial. PAU UGM, Yogyakarta.

Sopamena, J. 2019. Resiliensi Nafkah Rumah Tangga Pulau Kecil (Studi Kasus Pulau Wetar Kabupaten Maluku Barat Daya). Habitat 30(2): 79-87. DOI: 10.21776/ub.habitat.2019.030.2.10

Soselisa, Y.Y., Fauzia, L., and Salmiah. 2013. Pengaruh Karakteristik Sosial Ekonomi Masyarakat Terhadap Keberhasilan Pelaksanaan Program PNPM Mandiri Perkotaan. Journal of Agriculture and Agribusiness Socioeconomics 2(9). DOI: 10.4135/9781412950589.n924

Speranza, C. I., Wiesmann, U., and Rist, S. 2014. An Indicator Framework for Assessing Livelihood Resilience in the Context of Social-Ecological Dynamics. Global Environmental Change 28(1): 109-119. DOI: 10.1016/j.gloenvcha.2014.06.005

Sukarman. 2017. Supplementary Factor and Role of Brigade Operation Forest Fire at Way Kambas National Park. Jurnal Sylva Lestari 5(3): 104-115. DOI: 10.23960/js135104-115

Syaufina, L., and Hafni, D.A.F. 2018. Variabilitas Iklim dan Kejadian Kebakaran Hutan dan Lahan Gambut di Kabupaten Bengkalis, Provinsi Riau. Jurnal Silvikultur Tropika 9(1): 60-68.

Ukkas, I. 2017. Faktor-Faktor yang Mempengaruhi Produktivitas Tenaga Kerja Industri Kecil Kota Palopo. Journal of Islamic Education Management 2(2): 187-198. DOI: 10.24256/kelola.v2i2.440

Walker, B., Holling, C.S., Carpenter, S.R., and Kinzig, A. 2004. Resilience, Adaptability and Transformability in Social-Ecological Systems. Ecology and Society 9(2). DOI: 10.5751/ES00650-090205

Wijayanti, R., Baiquni, M., and Harini, R. 2016. Strategi Penghidupan Berkelanjutan Masyarakat Berbasis Aset di Sub DAS Pusur, DAS Bengawan Solo. Jurnal Wilayah dan Lingkungan 4(2): 133. DOI: $10.14710 /$ jwl.4.2.133-152

World Bank. 2015. Indonesia Economic Quarterly: Reforming amid uncertainty. Jakarta. Yin, R.K. 2011. Qualitative Research from Start to Finish. The Guilgorf Press, New York. 